\title{
Association and haplotype analysis of candidate genes in five genomic regions linked to sow maternal infanticide in a white Duroc $\times$ Erhualian resource population
}

Congying Chen, Zhuqing Yang, Yanying Li, Na Wei, Pinghua Li, Yuanmei Guo, Jun Ren, Nengshui Ding*, Lusheng Huang*

\begin{abstract}
Background: Maternal infanticide is an extreme and failed maternal behavior, which is defined as an active attack on piglets using the jaws, resulting in serious or fatal bite wounds. It brings big economic loss to the pig industry and severe problems to piglets' welfare. But little is known about the genetic background of this behavior. Quantitative trait loci (QTL) for maternal infanticide were identified in a White Duroc $\times$ Erhualian intercross by a non-parametric linkage analysis (NPL) in our previous study. In this study, associations of 194 microsatellite markers used in NPL analysis with maternal infanticide behavior were further analyzed by transmission-disequilibrium test (TDT). On this basis, seven genes (ESR2, EAAT2, BDNF, OXTR, 5-HTR2C, DRD1 and GABRA6) at five genomic regions were selected and further analyzed. Associations of single nucleotide polymorphisms (SNPs) and haplotypes in each gene with maternal infanticide behavior were evaluated.

Results: Microsatellite markers on pig chromosome (SSC) 2, 13, 15, and X displayed significance at $P<0.05$ by both TDT and NPL. Of the seven candidate genes, three ESR2 SNPs had nominal evidence for association $(P<$ 0.05). Allele A at EAAT2 g. 233G > A and allele T at DRD1 g.1013C > G > T also showed evidence of overtransmission to infanticidal sows. In the overall tests of association of haplotypes, candidate genes of ESR2, EAAT2 and DRD1 achieved overall significance level $(P<0.05)$. Haplotype $[A ; A ; G],[G ; A ; G],[A ; G ; G]$ and $[C ; C]$, respectively, from ESR2, EAAT2 and DRD1 showed higher frequencies to infanticidal sows $(P<0.05)$. Alleles among haplotypes and SNPs which showed an overtransmission to infanticidal sows were from White Duroc.
\end{abstract}

Conclusions: From association tests of SNPs and haplotypes, ESR2, EAAT2 and DRD1 showed significant associations with maternal infanticide. This result supported the existence of QTL for maternal infanticide behavior on SSC1, SSC2 and SSC16.

\section{Background}

Sows normally exhibit a series of maternal behaviors around parturition, but failure to establish normal maternal bonds with their newborn offspring occurs in some sows. An extreme behavior is maternal infanticide which is defined as an active attack of piglets that results in serious or fatal bite wounds around parturition or within 24 hours after parturition. From surveys

\footnotetext{
* Correspondence: dingyd2005@hotmail.com; Lushenghuang@hotmail.com Key Laboratory for Animal Biotechnology of Jiangxi Province and the Ministry of Agriculture of China, Jiangxi Agricultural University, Nanchang, 330045, PR China
}

(c) 2011 Chen et al; licensee BioMed Central Ltd. This is an Open Access article distributed under the terms of the Creative Commons Attribution License (http://creativecommons.org/licenses/by/2.0), which permits unrestricted use, distribution, and reproduction in any medium, provided the original work is properly cited. of large commercial pig farms in Europe, the incidence of maternal infanticide was $8 \%$ [1] or $7-12 \%$ [2]. The incidence in primiparous sows is as high as $10-13 \%$ $[2,3]$. It not only brings a big economic loss to the pig industry, but also leads to poor animal welfare of piglets.

The aetiology of maternal infanticide in pigs is not clear. Environment, hormonal, parturition experience and genetic factors are all associated with maternal infanticide. The heritability of maternal infanticide differs between estimates of daughter/sire $(0.12-0.25)$ and daughter/dam (0.5 - 0.9) [2]. It ranges between 0.4 and 0.9 and shows significant additive genetic effects in 
primiparous sows [1]. Quilter et al. (2007) detected four quantitative trait loci (QTL) for maternal infanticide on pig chromosomes (SSC) 2, 10 and $\mathrm{X}$ by non-parametric linkage analysis (NPL) in western commercial lines [4]. In our previous study, seven QTL were identified on SSC2, 6, 13, 14, 15 and X by NPL in a White Duroc $\times$ Erhualian $\mathrm{F}_{2}$ resource population [5].

Besides non-parametric linkage analysis, transmissiondisequilibrium test (TDT) has also been widely used to investigate chromosome regions responsible for schizophrenia, bipolar disorder and other diseases in humans [6] and pigs $[7,8]$. So we herein used TDT to confirm the NPL results and discover other regions associated with maternal infanticide. The loci showing significance in both NPL and TDT analysis were considered to be the most interesting for further analyses.

Four functional related candidate genes including excitatory amino acid transporter 2 (EAAT2), brain derived neurotrophic factor (BDNF), oxytocin receptor $(O X T R)$ and 5-hydroxytryptamine (serotonin) receptor $2 \mathrm{C}$ (5-HTR2C) on the chromosome 2, 13 and X where QTL for maternal infanticide were identified by both NPL and TDT were chosen for further association analysis. A possible association between the A/G polymorphism at position $949 \mathrm{nt}$ in ESR2 mRNA and susceptibility to maternal infanticide in western commercial sows was found by our European collaborators (personal communication, C. Sargent, University of Cambridge, UK). And based on important roles of estrogens in maternal behavior, the ESR2 gene was also analyzed for association with maternal infanticide behavior in the White Duroc $\times$ Erhualian resource population. A genomic region on SSC16 achieved near significance level $(P=0.067)$ in NPL analysis, so functional candidate genes of Gamma-aminobutyric acid receptor A6 (GABRA6) and dopamine receptor $D 1(D R D 1)$ were also investigated to confirm whether the QTL exited or not. Investigation of candidate genes in these regions could reveal causative genes for the maternal infanticide or linked markers, which would benefit marker-assisted selection (MAS) schemes for decreasing the incidence of maternal infanticide behavior.

\section{Results}

\section{Significant loci identified by TDT}

The significant loci revealed by TDT are presented in Table 1. Markers displaying significance at a corrected nominal value of $P<0.05$ were discovered on SSC2, 9, $10,11,13,15,17$ and $\mathrm{X}$. Especially on the X chromosome, all 15 genotyped markers showed strong significant association with maternal infanticide (corrected $P<$ 0.01 ). The significantly associated loci identified by both NPL and TDT analysis located on SSC2, 13, 15 and X.

\section{Significant markers of positional candidate genes}

Comparative sequencing of founder animals of the resource population identified the polymorphisms of

Table 1 The genomic regions linked to pig maternal infanticide behavior by transmission-disequilibrium test (TDT)

\begin{tabular}{|c|c|c|c|c|}
\hline chromosome & marker & position (cM) & Corrected $P$ value & $P$ value in NPL (Chen et al., 2009) \\
\hline 2 & SW1879 & 103.70 & 0.02 & $4.90 \mathrm{E}-3$ \\
\hline 9 & SW1349 & 144.10 & 0.02 & 0.10 \\
\hline 10 & SWC19 & 65.00 & 0.02 & 0.97 \\
\hline 11 & SW2413 & 106.30 & 0.01 & 0.40 \\
\hline 13 & S0283 & 83.50 & 0.03 & 0.04 \\
\hline 15 & SW1562 & 26.60 & 0.03 & 0.02 \\
\hline 17 & SWR1004 & 0.00 & 0.02 & 0.22 \\
\hline \multirow[t]{15}{*}{$x$} & SW980 & 27.80 & $1.63 \mathrm{E}-10$ & $1.00 \mathrm{E}-4$ \\
\hline & SW1903 & 40.40 & $5.03 \mathrm{E}-10$ & $1.78 \mathrm{E}-3$ \\
\hline & SW2456 & 48.10 & 3.01E-10 & $9.29 E-4$ \\
\hline & UMNP1174 & 52.80 & 0.01 & $2.54 \mathrm{E}-3$ \\
\hline & SWR1861 & 54.30 & $6.41 E-3$ & $3.26 \mathrm{E}-3$ \\
\hline & UMNP71 & 55.60 & $3.85 E-3$ & 5.01E-3 \\
\hline & SW1994 & 55.80 & $6.63 E-3$ & $5.62 E-3$ \\
\hline & SW259 & 56.40 & $1.35 \mathrm{E}-10$ & $5.57 \mathrm{E}-3$ \\
\hline & SW1426 & 58.50 & $5.13 E-3$ & $9.10 \mathrm{E}-3$ \\
\hline & SW1522 & 63.10 & $3.85 E-3$ & 0.01 \\
\hline & MCSI02 & 65.00 & 0.01 & 0.01 \\
\hline & SW1943 & 66.00 & $2.26 \mathrm{E}-10$ & 0.01 \\
\hline & SW1608 & 71.70 & $6.41 E-3$ & $9.00 \mathrm{E}-4$ \\
\hline & SW707 & 74.30 & $1.08 \mathrm{E}-10$ & 7.87E-3 \\
\hline & SW2588 & 90.00 & $3.76 \mathrm{E}-10$ & 0.02 \\
\hline
\end{tabular}


candidate genes. All exons, $5^{\prime}$ promoter region and part of introns of ESR2, BDNF, DRD1, OXTR and 5-HTR2C were screened. All sequences determined in this study have been deposited in GenBank with accession number HM754211, HM754212, HM754213, HM754214, HM754215, HM754216 and HM754217. The identified SNPs are given in Additional file 1, Table S1. Nine SNPs were detected in ESR2, including 6 in introns and 3 in exons. The mutation of $\mathrm{A}>\mathrm{G}$ in exon 5 causes a change of methionine to valine. The other two coding SNPs are synonymous mutations. All 12 SNPs were found in introns of $B D N F$. For DRD1, a total of 3 SNPs were detected in exons, and all are synonymous mutations. Three SNPs were identified in exon 2 and five in introns of OXTR, and all exonic SNPs in this gene were synonymous mutations. Only $1 \mathrm{SNP}$ was found in the 5-HTR2C gene which located at intron 3. For EAAT2 and GABRA6 genes, only parts of sequences were screened for variants. Comparative sequencing revealed 10 polymorphisms in intron 7 and 2 synonymous polymorphisms in exon 9 of the GABRA6 gene. Twelve SNPs were identified in the intronic regions of the EAAT2 gene. Haplotypes were constructed for each candidate gene and their frequencies are shown in Table 2. Rare haplotypes (frequency $<0.05$ ) were excluded from further analyses.

SNPs in which minor allele frequencies (MAF) were > 0.15 (Table 2) were chosen for genotyping animals in the resource population. Family-based association analysis was carried out on a total of 18 SNPs from seven candidate genes (Table 2). The significantly associated markers were found in ESR2, EAAT2 and DRD1. Allele A of ESR2 g.1170 G > A and g. 1202G > A (HM754215), allele $G$ of ESR2 g. 2681G > T (HM754215) showed evidences of significant overtransmission of the major alleles to infanticidal sows $(P<0.05)$. Allele $A$ of g. $233 \mathrm{G}>\mathrm{A}$ in EAAT2 (HM754214) also showed a significant overtransmission of the major allele to infanticidal sows $(P<0.01)$. The overall $P$ value of $\mathrm{g} .1013 \mathrm{C}>\mathrm{G}>\mathrm{T}$ in $D R D 1$ (HM754213) also achieved $<0.01$ significance level, and allele $C$ more frequently transmitted to infanticidal sows. For 5-HTR2C, although no allele showed significantly different transmission between infanticidal sows and normal sows, allele A had a higher frequency transmitted to infanticidal sows $(P=0.088)$. Interestingly, through checking the origin of alleles, we found that all alleles which had overtransmission to infanticidal sows were from White Duroc.

To further support the evidences of association, the overall tests of association were also performed on haplotypes. Only ESR2, EAAT2 and DRD1 showed significantly overall $P$ value (Table $2 ; P<0.05$ ). Haplotypes $[\mathrm{A} ; \mathrm{A} ; \mathrm{G}]$ and $[\mathrm{G} ; \mathrm{A} ; \mathrm{G}]$ from $E S R 2,[\mathrm{~A} ; \mathrm{G} ; \mathrm{G}]$ from $E A A T 2$, and $[C ; C]$ from $D R D 1$ showed an overtransmission to infanticidal sows. All these haplotypes were from the breed of White Duroc.

\section{Discussion}

Maternal infanticide behavior, a lacking of a clear Mendelian inheritance pattern, could be caused by several genes of low to moderate penetrance, TDT or NPL analysis are hence a more robust and successful alternative to identify susceptible loci for the abnormal behavior. As in other studies [7,9], we found distinct linkage results between TDT and NPL [5]. NPL test for markers linked to genes affecting disease status on the basis of identity-by-descent, and is more powerful when the marker density is low. TDT is a fine mapping method requiring linkage disequilibrium (LD) between causative mutations and the linked markers $[8,10]$. It shows greater power when markers are very close to the causative gene. In this study, the discrepancy between TDT and NPL may be caused by the low marker density and the multiple marker alleles.

Seven candidate genes, of which EAAT2, BDNF, OXTR and $5 H T R 2 C$ are positional and functional candidate genes, and ESR2, DRD 1 and GABRA6 are functional candidate genes, were chosen from five genomic regions including SSC1, SSC2, SSC13, SSC16 and SSCX for further analyzing to find candidate markers linked to sow maternal infanticide behavior. Significant associations were identified on all three ESR2 SNPs, and the overall test of association of the haplotypes also achieved the significance level. Haplotypes of [G;G;T] and $[A ; A ; G]$ showed very significant transmission disequilibrium between normal and infanticidal sows $(P<$ $0.01)$. Estrogen and progesterone are important in the initiation of maternal behavior [11]. Estrogens have generally excitatory effects [12] and considerable regulatory influence on systems mediating anxiety and mood [13]. Sows with high ratio of estrogen to progesterone in late pregnancy showed increased savaging to their piglets [14]. Estrogen's actions could be mediated by estrogen receptor 1 or 2 ( $\alpha$ or $\beta$ ). ESR 1 is critical for reproduction function, and ESR2 is critically involved in regulating reproductive behaviors, brain development and procession of emotional behavior (anxiety-related behavior e.g.) [15]. This result was also consistent with the results in western commercial sows (personal communication, C. Sargent, University of Cambridge, UK), in which an $\mathrm{A} / \mathrm{G}$ polymorphism at position $949 \mathrm{nt}$ of ESR2 mRNA was associated with maternal infanticide. However, no QTL was detected on SSC1 in whole genome QTL mapping. It could be caused by low marker density tested on this chromosome.

Another significant association was found on EAAT2 gene. Extreme significance level was achieved both in analyses of g. 233G $>$ A and haplotypes $(P<0.01$, 
Table 2 Associations of the SNPs and haplotypes in ESR2, EAAT2, BDNF, GABRA6, DRD1, OXTR and 5-HTR2C genes with sow maternal infanticide behavior

\begin{tabular}{|c|c|c|c|c|c|c|c|c|}
\hline \multirow[t]{2}{*}{ gene } & \multirow[t]{2}{*}{ Polymorphism } & \multirow[t]{2}{*}{ Allele or Haplotype ${ }^{1}$} & \multirow[t]{2}{*}{ Allele or Haplotype Frequency } & \multicolumn{5}{|c|}{ Individuals of maternal infanticide } \\
\hline & & & & $\mathrm{T}$ & UT & DF & LRS & $P$ \\
\hline \multirow[t]{9}{*}{ ESR2 (HM754215) } & g.1170 G > A & $A$ & 0.341 & 40 & 24 & 1 & 4.043 & $0.044^{*}$ \\
\hline & & G & 0.659 & 24 & 40 & & & \\
\hline & g. $1202 \mathrm{G}>\mathrm{A}$ & $A$ & 0.501 & 52 & 29 & 1 & 6.623 & $0.010^{*}$ \\
\hline & & G & 0.499 & 29 & 52 & & & \\
\hline & g. $2681 \mathrm{G}>\mathrm{T}$ & G & 0.534 & 50 & 28 & 1 & 6.290 & $0.012 *$ \\
\hline & & $T$ & 0.466 & 28 & 50 & & & \\
\hline & - & GGT & 0.457 & 10 & 30 & 2 & 5.993 & $0.049 *$ \\
\hline & - & GAG & 0.143 & 7 & 2 & & & \\
\hline & - & $A A G$ & 0.361 & 23 & 8 & & & \\
\hline \multirow[t]{9}{*}{ EAAT2 (HM754214) } & g. $233 \mathrm{G}>\mathrm{A}$ & $A$ & 0.693 & 43 & 20 & 1 & 8.594 & $0.003^{*}$ \\
\hline & & G & 0.307 & 20 & 43 & & & \\
\hline & g.489G > A & $A$ & 0.235 & 19 & 28 & 1 & 1.734 & 0.188 \\
\hline & & G & 0.765 & 28 & 19 & & & \\
\hline & g. $1028 \mathrm{G}>\mathrm{A}$ & $A$ & 0.238 & 20 & 29 & 1 & 1.662 & 0.197 \\
\hline & & G & 0.762 & 29 & 20 & & & \\
\hline & - & $A G G$ & 0.652 & 29 & 6 & 2 & 10.124 & $0.007^{*}$ \\
\hline & - & GAA & 0.278 & 4 & 20 & & & \\
\hline & - & GGG & 0.070 & 2 & 11 & & & \\
\hline \multirow[t]{10}{*}{ BDNF (HM754212) } & g.612C > A & C & 0.748 & 27 & 19 & 1 & 1.391 & 0.238 \\
\hline & & $A$ & 0.252 & 19 & 27 & & & \\
\hline & g. $2723 G>A$ & G & 0.513 & 37 & 45 & 1 & 0.781 & 0.377 \\
\hline & & $A$ & 0.487 & 45 & 37 & & & \\
\hline & g.3481A > G & $A$ & 0.594 & 33 & 31 & 1 & 0.063 & 0.803 \\
\hline & & G & 0.406 & 31 & 33 & & & \\
\hline & - & $A A A$ & 0.245 & 9 & 12 & 3 & 3.762 & 0.288 \\
\hline & - & $C A A$ & 0.241 & 19 & 8 & & & \\
\hline & - & CGA & 0.108 & 4 & 9 & & & \\
\hline & - & CGG & 0.394 & 16 & 19 & & & \\
\hline \multirow[t]{10}{*}{ OXTR (HM754217) } & g.509G > A & G & 0.811 & 21 & 15 & 1 & 1.000 & 0.316 \\
\hline & & $A$ & 0.189 & 15 & 21 & & & \\
\hline & g. $1211 \mathrm{~T}>\mathrm{C}$ & $T$ & 0.487 & 26 & 35 & 1 & 1.333 & 0.248 \\
\hline & & C & 0.513 & 35 & 26 & & & \\
\hline & g. $2271 \mathrm{C}>\mathrm{T}$ & C & 0.836 & 13 & 21 & 1 & 1.900 & 0.168 \\
\hline & & $T$ & 0.164 & 21 & 13 & & & \\
\hline & - & $A C C$ & 0.193 & 15 & 8 & 3 & 2.350 & 0.503 \\
\hline & - & $G \pi$ & 0.146 & 10 & 16 & & & \\
\hline & - & GTC & 0.357 & 15 & 18 & & & \\
\hline & - & GCC & 0.304 & 21 & 19 & & & \\
\hline \multirow[t]{9}{*}{ DRD1 (HM754213) } & g.1013C > G > T & C & 0.500 & 47 & 35 & 2 & 9.485 & $0.009 *$ \\
\hline & & G & 0.424 & 28 & 46 & & & \\
\hline & & $T$ & 0.076 & 7 & 1 & & & \\
\hline & g. $1655 C>T$ & C & 0.795 & 26 & 17 & 1 & 1.898 & 0.168 \\
\hline & & $T$ & 0.205 & 17 & 26 & & & \\
\hline & - & GT & 0.205 & 5 & 17 & 3 & 10.068 & $0.018^{*}$ \\
\hline & - & TC & 0.066 & 7 & 1 & & & \\
\hline & - & CC & 0.511 & 30 & 18 & & & \\
\hline & - & GC & 0.218 & 6 & 12 & & & \\
\hline \multirow[t]{2}{*}{ GABRA6 (HM754216) } & g. $176 \mathrm{C}>\mathrm{T}$ & $\mathrm{T}$ & 0.266 & 30 & 37 & 1 & 0.546 & 0.460 \\
\hline & & C & 0.734 & 37 & 30 & & & \\
\hline
\end{tabular}


Table 2 Associations of the SNPs and haplotypes in ESR2, EAAT2, BDNF, GABRA6, DRD1, OXTR and 5-HTR2C genes with sow maternal infanticide behavior (Continued)

\begin{tabular}{|c|c|c|c|c|c|c|c|c|}
\hline & g. $444 \mathrm{~A}>\mathrm{T}$ & A & 0.576 & 29 & 35 & 1 & 0.563 & 0.453 \\
\hline & & T & 0.424 & 35 & 29 & & & \\
\hline & g.1520G > A & T & 0.590 & 29 & 34 & 1 & 0.397 & 0.529 \\
\hline & & G & 0.410 & 34 & 29 & & & \\
\hline & - & TTG & 0.521 & 15 & 18 & 2 & 4.510 & 0.123 \\
\hline & - & CAT & 0.257 & 15 & 17 & & & \\
\hline & - & $\mathrm{CTG}$ & 0.132 & 11 & 3 & & & \\
\hline 5-HTR2C (HM754211) & g.675C > T & A & 0.606 & 15 & 7 & 1 & 2.909 & 0.088 \\
\hline & & G & 0.394 & 7 & 15 & & & \\
\hline
\end{tabular}

Note: T: Transmission; UT: Untransmission; LRS: likelihood ratio statistic. The likelihood ratio statistic is minus twice the difference in log-likelihoods; P: P value from the overall test of association; DF: degree of freedom.

*: significant in statistics.

1. Rare haplotypes were excluded from association study.

Table 2). Although the significant microsatellite marker and $E A A T 2$ gene were not in the same genomic region on SSC2, this result should confirm the existence of QTL on this chromosome owning to large linkage disequilibrium in $\mathrm{F}_{2}$ population. EAAT2 is responsible for the majority of glutamate uptake in the brain and its disregulation has been associated with multiple psychiatric and neurological disorders [16]. Its expression in infanticidal sows from the current population is downregulated (Data from cDNA microarray analysis, unpublished). Combined with the association result in this study, it is a strong candidate gene for maternal infanticide.

The last significant association was identified on $D R D 1$ gene. DRD 1 encodes the D1 subtype of the dopamine receptor. D1 receptors regulate neuronal growth and development, mediates some behavioral responses and schizophrenia $[17,18]$. Given the differently transmitted frequency of the $D R D 1$ alleles and its important roles in behavioral responses, $D R D 1$ could be an important candidate gene influencing sow maternal infanticide behavior. The significant association of DRD1 with maternal infanticide indicated that a causative gene may exist within this chromosome region. Only five microsatellite markers on SSC16 were used in the whole genome QTL scanning, therefore the absence of a QTL on this chromosome may be due to low marker density.

Interestingly, the alleles both in SNPs and haplotypes which had overtransmission to infanticidal sows were from White Duroc. This result was also consistent with the previous reports about maternal ability of Chinese and Western pig breeds. The Chinese Erhualian pig breed is the most famous Chinese indigenous pig breed for its excellent reproductive performance. Van der Steen and de Groot (1992) found that Meishan piglets have $5 \%$ advantage in survival rate than large white piglets due to good maternal behavior [19]. The Chinese Meishan breed exhibits good maternal characteristics with resulting even heavier piglets at weaning and lower incidence of aggressive behavior towards their offspring than European white sows [20].

The other candidate genes, such as BDNF, OXTR and GABRA6, which play important roles in the phenotypes similarly to maternal infanticide behavior, for example anxiety-related behavior [21], mood disorders [22], depression-related traits [23] and pressure response [24], did not show any significant association with maternal infanticide behavior in this study. So these genes are not the candidate genes for maternal infanticide in the White Duroc $\times$ Erhualian resource population, or more SNPs in these genes needed to be evaluated. Especially for OXTR gene, in rats, females having a significantly high expression level of oxytocin receptors in several areas of brain showed more maternal care to offspring [25], and the oxytocin receptor gene located proximal to a QTL on SSC13 detected by both NPL and TDT. However, the QTL on this chromosome only achieved $P<$ 0.05 significance level, false discovery can not be excluded.

For chromosome X, similarly to the results in NPL [9] and western commercial pig lines [8], all 15 microsatellite markers showed very significant association with maternal infanticide behavior in the TDT analysis. 5HTR2C shows close relationship with anxiety-like behavior and major mental disorders including schizophrenia, bipolar disorder and major depression [26,27]. In this study, allele $A$ of g.675C > T (HM754211) was preferably transmitted to infanticidal sows compared with allele $\mathrm{C}$. The $P$ value did not achieve statistical significant level due to the small population size, or more SNPs in this gene or more candidate genes need to be analyzed.

\section{Conclusions}

Microsatellite markers on SSC2, 13, 15 and X were identified to associate with maternal infanticide both by 
NPL and TDT analysis. From the overall association test of SNPs and haplotypes in seven candidate genes, ESR2, $E A A T 2$ and DRD1 gene showed significant association with sow maternal infanticide. Given the extensive linkage disequilibrium in a $F_{2}$ population, although some candidate genes showed highly significant association with maternal infanticide behavior, they are more likely linked genes rather than causal genes. The association results provided the evidence for locating the QTL, and would provide some useful information for future studies directing at the identification of the causative mutations.

\section{Methods}

\section{Animals}

A $F_{2}$ resource population was developed using two divergent pig breeds of White Duroc and Chinese Erhualian. Two White Duroc boars and 17 Erhualian sows were crossed as founder animals to produce $F_{1}$ animals, and $59 \mathrm{~F}_{1}$ sows were randomly mated with $9 \mathrm{~F}_{1}$ boars to produce $1912 \mathrm{~F}_{2}$ individuals, of which $288 \mathrm{~F}_{2}$ sows from 83 families were well phenotyped for maternal behaviors around parturition over three continuous farrowings. Each sow was housed in a pen of $2 \times 2.5$ meters with a concrete floor, solid walls of 1 meter high during the giving birth. The feeding and management of the sows were described in detail in Chen et al. 2008 [3]. All animal procedures were conducted according to the guidelines for the care and use of experimental animals established by the Ministry of Agriculture of China.

\section{Phenotype recording}

Sow maternal behavior was observed and recorded from 6 hours before parturition to 24 hours after giving birth. The methods for phenotypic records were described previously [3]. In brief, from the first piglet's birth, sow maternal infanticide was recorded, which was defined as an apparently deliberate attack on one or more piglets that resulted in a serious wound or the death by biting of at least one piglet. Sows with infanticide behavior were marked 1 , conversely marked 0 . The phenotypic records were performed on $288 \mathrm{~F}_{2}$ sows at their first to third farrowings. A total of 47 sows showed maternal infanticide behavior.

\section{Identification of polymorphisms in candidate genes}

Genomic DNA was isolated from porcine ear tissues using proteinese $\mathrm{K}$ digestion followed by phenol/chloroform extraction and precipitation with ethanol. DNA of founder animals or nine $F_{1}$ boars was used for detecting polymorphisms. Primers were designed based upon the genomic DNA sequence at Ensemble (Sscrofa9, Apr 2009) [28] using software Primer 5.0. Primer sequences, amplified gene region, length of amplicons and their annealing temperature are shown on Additional file 1, Table S1. Amplification was performed in a $20 \mu \mathrm{l}$ reaction volume containing $40 \mathrm{ng}$ genomic DNA template, $0.4 \mu \mathrm{l}$ of each dNTP $(0.2 \mathrm{mM}), 0.3 \mu \mathrm{l}$ of each primer $(0.2 \mu \mathrm{M})$ and $2 \mathrm{U}$ of Taq DNA polymerase (Takara, Dalian, China) at $94^{\circ} \mathrm{C}$ for $5 \mathrm{~min}, 35 \times\left(94^{\circ} \mathrm{C}\right.$ for $30 \mathrm{sec}$, annealing temperature for $30 \mathrm{sec}, 72^{\circ} \mathrm{C}$ for $45 \mathrm{sec}$ ), $72^{\circ} \mathrm{C}$ for 7 min on PTC-200 Thermal Cyclers (Bio-RAD, Waltham, USA). After purified with the QIAquick DNA Purification Kit (Qiagen, Hilden, Germany), PCR products were bidirectly sequenced by BigDye Terminator v3.1 on an ABI3130XL genetic analyzer (Applied Biosystems, Foster, USA). The obtained genomic sequences were analyzed for SNPs using Chromas or SeqMan.

\section{Genotyping}

The selection and genotyping of 194 microsatellite markers in the whole scan were described in detail in Chen et al. 2009 and Guo et al. 2009 [9,29]. Except 5-HTR2C and $D R D 1$ in which only one and two identified SNPs were genotyped, respectively, three SNPs from each candidate gene were selected according to their polymorphic information (MAF > 0.15) and genotyped in the resource population. SNPs of EAAT2 and GABRA6 were genotyped by PCR-RFLP using primers in Additional file 1, Table S2. For the SNP of GABRA6 g.176C > T and the SNP of EAAT2 g.233G > A, a primer mutagenesis assay was established for these sites. For the SNP of GABRA6 g.176C > T, a mismatch nucleotide $(\mathrm{G})$ was incorporated at position 29 of the forward primer to amplify a fragment of $250 \mathrm{bp}$, and for the SNP of EAAT2 g.233G > A, the mismatch nucleotide $(\mathrm{G})$ was located at position 28 of the forward primer (Additional file 1, Table S2). Five microliter PCR products were digested in a volume of 15 $\mu \mathrm{l}$ containing $2 \mathrm{U}$ restriction enzymes (NEB, Beijing, China) and $1 \times$ supplied buffer by incubating at $37^{\circ} \mathrm{C}$ water for $6 \mathrm{~h}$. The restriction fragments were separated on $2 \%$ agarose gels in $1 \times \mathrm{TAE}$ buffer at constant voltage of $180 \mathrm{~V}$. The gels were stained with ethidium bromide and visualized on an UV transilluminator.

The ESR2, BDNF, DRD1, OXTR and 5-HTR2C SNPs were genotyped using the SNaPshot kit (Applied Biosystems, Foster, USA) according to the manufacturers' protocol. Briefly, PCR reaction was performed as described above. Three microlitre PCR products were purified with $1 \mu \mathrm{l}$ enzyme of ExoSap-IT (USB, USA) at $37^{\circ} \mathrm{C}$ for $15 \mathrm{~min}$, followed by $80^{\circ} \mathrm{C}$ for $15 \mathrm{~min}$. Three SNPs in each gene were genotyped in a single $\mathrm{SNaPshot} \mathrm{reaction.}$ The SNaPshot reaction was performed at $5 \mu \mathrm{l}$ mixture containing $2 \mu \mathrm{l}$ SNaPshot Multiplex Ready Reaction Mix, $0.5 \mu \mathrm{l}$ mixed SNaPshot primers and $2.5 \mu \mathrm{l}$ mixed purified PCR products at $35 \times\left(96^{\circ} \mathrm{C}\right.$ for $10 \mathrm{sec}, 50^{\circ} \mathrm{C}$ for $10 \mathrm{sec}, 60^{\circ} \mathrm{C}$ for $30 \mathrm{sec}$ ) on PTC-200 Thermal Cyclers 
(Bio-RAD, Waltham, USA). Primers for PCR and SNaPshot extension assays are listed in Additional file 1, Table S3. The SNaPshot reaction product was purified with $1 \mathrm{U}$ CIP (NEB, Beijing, China) at $37^{\circ} \mathrm{C}$ for $1 \mathrm{~h}$, followed by $75^{\circ} \mathrm{C}$ for $15 \mathrm{~min}$. Eight microlitre Hi-Di were mixed with $0.5 \mu \mathrm{l}$ purified SNaPshot product, $0.4 \mu \mathrm{l}$ GeneScan 120 LIZ size standard and $1.1 \mu$ distilled water. After denaturalized at $95^{\circ} \mathrm{C}$ for $5 \mathrm{~min}$, the mixture was placed immediately on ice, and then loaded on an ABI 3130XL genetic analyzer for data collection. The SNP genotypes were recorded by GeneScan version 4.0.

\section{Statistical analysis}

The classical transmission-disequilibrium test (TDT) and the sib transmission-disequilibrium test (S-TDT) were performed with TDT-STDT program version 1.1 under defaulted settings [30,31] for the 194 microsatellite markers. Bonferroni correction was used to remove the effect of multiple tests and determine the significant $P$ value. SNP genotypes were corrected for Mendelian errors using FBAT software. To eliminate stratification effects, family-based association analysis of each SNP marker and haplotype was carried out using transmission-disequilibrium test (TDT) via the TDTPHASE software in UNPHASED package [32]. In this analysis, the overall test of association was the likelihood ratio test. The log-likelihoods for the null and alternative hypotheses were displayed. The p-value was the probability of observing a likelihood ratio statistic at least as large as this one, if the null hypothesis were true [32]. Only complete trios and one trio per multiplex family were included. Linkage disequilibrium values were measured from genotype data of $F_{2}$ individuals using 2LD software [33]. Individuals' haplotypes were constructed using Simwalk2 software [34]. Rare haplotypes at frequencies lower than 0.05 were excluded from the test.

\section{Additional material}

Additional file 1: sequences and assay conditions of primers for SNPs identification and genotyping

\footnotetext{
Acknowledgements

This work was supported by National Natural Science Foundation (30760164) and National Basic Research Program of China (973 Program)

\section{Authors' contributions}

Conceived and designed the experiments: LSH. Performed the experiments: CYC, ZQY, YYL, NW and PHL. Analyzed the data: NSD, CYC, ZQY, YYL and YMG. Wrote and revised the paper: CYC, LSH. Provided comments and suggestions for the manuscript: JR. All authors read and approved the final manuscript.
}

Received: 5 October 2010 Accepted: 9 February 2011

Published: 9 February 2011
References

1. Knap PW, Merks JWM: A note on the genetics of aggressiveness of primiparous sows towards their piglets. Livest. Pro. Sci 1987, 17:161-167.

2. van der Steen $H A$, Schaeffer $L R$, de Jong $H$, de Groot PN: Aggressive behavior of sows at parturition. J. Anim. Sci 1988, 66:271-279.

3. Chen C, Gilbert CL, Yang G, Guo Y, Segonds-Pichon A, Ma J, Brenig B, Sargent CA, Affara NA, Huang L: Maternal infanticide in sows: Incidence and behavioural comparisons between savaging and non-savaging sows at parturition. Appl. Anim. Behav. Sci 2008, 109:238-248.

4. Quilter CR, Blott SC, Wilson AE, Bagga MR, Sargent CA, Oliver GL, Southwood Ol, Gilbert CL, Mileham A, Affara NA: Porcine maternal infanticide as a model for puerperal psychosis. Am. J. Med. Genet. B Neuropsychiatr. Genet 2007, 144:862-868.

5. Chen C, Guo Y, Yang G, Yang Z, Zhang Z, Yang B, Yan X, Perez-Enciso M, Ma J, Duan Y, Brenig B, Huang L: A genome wide detection of quantitative trait loci on pig maternal infanticide behavior in a large scale White Duroc × Erhualian resource population. Behav. Genet 2009, 39:213-219.

6. Mujaheed M, Corbex M, Lichtenberg P, Levinson DF, Deleuze JF, Mallet J, Ebstein RP: Evidence for linkage by transmission disequilibrium test analysis of a chromosome 22 microsatellite marker D22S278 and bipolar disorder in a Palestinian Arab population. Am. J. Med. Genet. B Neuropsychiatr. Genet 2000, 96:836-838.

7. Ding NS, Mao HR, Guo YM, Ren J, Xiao SJ, Wu GZ, Shen HQ, Wu LH, Ruan GF, Brenig B, Huang LS: A genome-wide scan reveals candidate susceptibility loci for pig hernias in an intercross between White Duroc and Erhualian. J. Anim. Sci 2009, 87:2469-2474

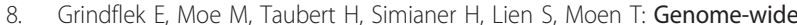
linkage analysis of inguinal hernia in pigs using affected sib pairs. BMC Genet 2006, 7:25

9. Wiedemann S, Fries R, Thaller G: Genomewide scan for anal atresia in swine identifies linkage and association with a chromosome region on Sus scrofa chromosome 1. Genetics 2005, 171:1207-1217.

10. Spielman RS, Ewans WJ: The TDT and other family-based tests for linkage disequilibrium and association. Am. J. Hum. Genet 1996, 59:983-989.

11. Kendrick KM, Keverne EB: Importance of progesterone and oestrogen priming for the induction of maternal behaviour by vaginocervical stimulation in sheep: effects of maternal experience. Physiol. Behav 1991, 49:745-750.

12. Smith MJ, Adams LF, Schmidt PJ, Rubinow DR, Wassermann EM: Effects of ovarian hormones on human cortical excitability. Ann. Neurol 2002, 51:599-603.

13. Fink G, Sumner BE, Rosie R, Grace O, Quinn JP: Estrogen control of central neurotransmission: effect on mood, mental state, and memory. Cell Mol. Neurobiol 1996, 16:325-344.

14. McLean KA, Lawrence AB, Petherick JC, Deans L, Chirnside J, Vaughan A Nielsen BL, Webb R: Investigation of the relationship between farrowing environment, sex steroid concentrations and maternal aggression in gilts. Anim. Reprod. Sci 1998, 50:95-109.

15. Lund TD, Rovis T, Chung WC, Handa RJ: Novel actions of estrogen receptor-beta on anxiety-related behaviors. Endocrinology 2005 , 146:797-807

16. Lauriat $T L$, Mclnnes $L A$ : EAAT2 regulation and splicing: relevance to psychiatric and neurological disorders. Mol. Psychiatry 2007, 2:1065-1078.

17. Severino G, Congiu D, Serreli C, De Lisa R, Chillotti C, Del Zompo M, Piccardi MP: A48G polymorphism in the D1 receptor genes associated with bipolar I disorder. Am. J. Med. Genet. B Neuropsychiatr. Genet 2005, 34B:37-38

18. Grymek K, Łukasiewicz S, Faron-Góreckaa A, Tworzydlo M, Polit A, Dziedzicka-Wasylewska M: Role of silent polymorphisms within the dopamine D1 receptor associated with schizophrenia on D1-D2 receptor hetero-dimerization. Pharmacol. Rep 2009, 61:1024-1033.

19. Van der Steen HA, de Groot PN: Direct and maternal breed effects on growth and milk intake of piglets: Meishan versus Dutch breeds. Livest. Prod. Sci 1992, 30:361-373.

20. Sinclair AG, Edwards SA, Hoste S, McCartney A: Evaluation of the influence of maternal and piglet breed differences on behaviour and production of Meishan synthetic and European White breeds during lactation. Anim. Sci 1998, 66:423-430 
21. Gadow KD, Roohi J, DeVincent CJ, Kirsch S, Hatchwell E: Association of COMT (Val158Met) and BDNF (Val66Met) gene polymorphisms with anxiety, ADHD and tics in children with autism spectrum disorder. J. Autism Dev. Disord 2009, 39:1542-1551.

22. Dunham JS, Deakin JF, Miyajima F, Payton A, Toro CT: Expression of hippocampal brain-derived neurotrophic factor and its receptors in Stanley consortium brains. J. Psychiatr. Res 2009, 43:1175-1184.

23. Sen S, Villafuerte S, Nesse R, Stoltenberg SF, Hopcian J, Gleiberman L, Weder A, Burmeister M: Serotonin transporter and GABAA alpha 6 receptor variants are associated with neuroticism. Biol. Psychiatry 2004, 55:244-249.

24. Uhart M, McCaul ME, Oswald LM, Choi L, Wand GS: GABRA6 gene polymorphism and an attenuated stress response. Mol. Psychiatry 2004, 9:998-1006.

25. Champagne FA, Diorio J, Sharma S, Meaney MJ: Naturally occurring variations in maternal behaviour in the rat are associated with differences in estrogen-inducible central oxytocin receptors. Proc. Natl. Acad. Sci. USA 2001, 98:12736-127341.

26. Kimura A, Stevenson PL, Carter RN, Maccoll G, French KL, Paul Simons J, AlShawi R, Kelly V, Chapman KE, Holmes MC: Overexpression of 5-HT2C receptors in forebrain leads to elevated anxiety and hypoactivity. Eur. $J$. Neurosci 2009, 30:299-306.

27. Iwamoto $\mathrm{K}$, Bundo $\mathrm{M}$, Kato $\mathrm{T}$ : Serotonin receptor $2 \mathrm{C}$ and mental disorders: genetic, expression and RNA editing studies. RNA Biol 2009, 6:248-253.

28. The Pig genome assembly in Ensembl. [http://www.ensembl.org/ Sus_scrofa/t

29. Guo YM, Mao HR, Ren J, Yan XM, Duan YY, Yang GC, Ren DR, Zhang ZY, Yang B, Ouyang J, Brenig B, Haley CS, Huang LS: A linkage map of the porcine genome from a large scale White Duroc $\times$ Erhualian resource population and evaluation of factors affecting recombination rates. Anim. Genet 2009, 40:47-52

30. Spielman RS, Ewens WJ: A sibship test for linkage in the presence of association: The sib transmission/disequilibrium test. Am. J. Hum. Genet 1998, 62:450-458.

31. Spielman RS, McGinnis RE, Ewens WJ: Transmission test for linkage disequilibrium: The insulin gene region and insulin-dependent diabetes mellitus (IDDM). Am. J. Hum. Genet 1993, 52:506-516.

32. Dudbridge F: Pedigree disequilibrium tests for multilocus haplotypes. Genet. Epidemiol 2003, 25:115-121.

33. Zapata C, Carollo C, Rodriguez S: Sampling variance and distribution of the $D^{\prime}$ measure of overall gametic disequlibrium between multiallelic loci. Ann. Hum. Genet 2001, 65:395-406.

34. Zhao JH: 2LD, GENECOUNTING and HAP: Computer programs for linkage disequilibrium analysis. Bioinformatics 2004, 20:1325-1326.

doi:10.1186/1471-2156-12-24

Cite this article as: Chen et al: Association and haplotype analysis of candidate genes in five genomic regions linked to sow maternal infanticide in a white Duroc $\times$ Erhualian resource population. BMC Genetics 2011 12:24.

\section{Submit your next manuscript to BioMed Central and take full advantage of:}

- Convenient online submission

- Thorough peer review

- No space constraints or color figure charges

- Immediate publication on acceptance

- Inclusion in PubMed, CAS, Scopus and Google Scholar

- Research which is freely available for redistribution

Submit your manuscript at www.biomedcentral.com/submit
Biomed Central 